Review Article

\title{
Research describing pelvifemoral rhythm: a systematic review
}

\author{
Richard W Bohannon, PT, EdD ${ }^{1)^{*}}$, Aaron Bass, BS ${ }^{2)}$ \\ 1) Department of Physical Therapy, College of Pharmacy and Health Sciences, Campbell University: \\ Lillington, NC, USA \\ 2) Holt Physical Therapy and Performance Training, USA
}

\begin{abstract}
Purpose] This systematics review was undertaken to synthesize what is known regarding pelvifemoral rhythm, that is, the coordinated flexion of the thigh and posterior tilting of the pelvis during hip flexion (HF). [Methods] Three databases were searched. [Results] Nine relevant articles were identified via independent database searches and a hand search by the authors. The articles were consistent in showing that pelvifemoral rhythm underlies the HF motion under conditions as varied as passive unilateral flexion while supine and active bilateral flexion while hanging from a bar. Posterior pelvic tilting, which begins early during HF, contributes between $13.1 \%$ to $37.5 \%$ of total HF. Pelvic tilting and HF excursions are highly correlated ( $\mathrm{r}=0.89$ to 1.00$)$. [Conclusions] Pelvifemoral rhythm is present to varying degrees during hip flexion under diverse conditions.

Key words: Lower limbs, Kinematics, Coordination
\end{abstract}

(This article was submitted Jul. 25, 2017, and was accepted Aug. 9, 2017)

\section{INTRODUCTION}

Hip flexion (HF); that is, sagittal plane movement of the thigh toward the anterior trunk, is required for the successful performance of many every-day and sporting activities. An understanding of the kinematics of the movement is therefore important. Numerous researchers have described the kinematics of the movement and in doing so have noted that it is multifaceted. Specifically, it involves a simultaneous movement of the thigh (femur) on the pelvis and a posterior tilting of the pelvis (PTT) ${ }^{1-9)}$, together known as pelvifemoral rhythm. It also involves a flattening of the lumbar spine ${ }^{11,12)}$. This review was undertaken to synthesize what is known about pelvifemoral rhythm during HF. Only the concentric phase of the movement was of interest and only during simple HF. Thus, the more complex kinimatics observed during activities such as walking, climbing, and kicking were ignored.

\section{METHODS}

Relevant literature was identified through the search of 3 electronic databases: Scopus, PubMed, and EBSCOHost (CINAHL). The searches were conducted in February of 2017 and involved the search string (pelvic OR pelvis) AND (motion OR rhythm) AND thigh. Searches were limited, as possible, to articles in English and to adults. A hand search based on an examination of article reference lists was also conducted.

To be included an article had to quantitatively describe movement of both the thigh and pelvis during hip flexion. Articles were excluded if they described the position of the thigh and pelvis during the static maintenance of hip flexion or during complex activities such as walking1).

Articles deemed appropriate based on inclusion and exclusion criteria were examined and information was extracted

*Corresponding author. Richard W Bohannon (E-mail: bohannon@campbell.edu)

(C2017 The Society of Physical Therapy Science. Published by IPEC Inc.

(c) (1) $\odot$ This is an open-access article distributed under the terms of the Creative Commons Attribution Non-Commercial No Derivatives

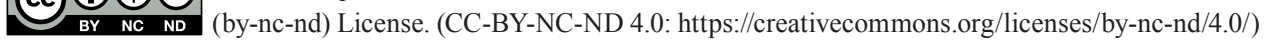


that related to participants, their postural orientation during testing, marking of the pelvis and lower limb, hip flexion task specifics, and findings regarding pelvifemoral rhythm (Table 1). The quality of articles contributing to the review were scored using a custom 8 item checklist with a maximum possible score of 16 (Table 2).

Table 1. Summary of articles addressing pelvifemoral rhythm in systematic review

\begin{tabular}{|c|c|c|c|c|c|}
\hline Article & Participants & $\begin{array}{c}\text { Postural } \\
\text { orientation }\end{array}$ & $\begin{array}{c}\text { Component } \\
\text { segment marking }\end{array}$ & $\begin{array}{c}\text { Hip flexion } \\
\text { task specifics }\end{array}$ & $\begin{array}{c}\text { Pelvifemal } \\
\text { rhythm findings }\end{array}$ \\
\hline $\begin{array}{l}\text { Bohannon } \\
(1982)^{2)}\end{array}$ & $\begin{array}{l}\text { Healthy young } \\
\text { males \& females } \\
(n=11)\end{array}$ & Supine & $\begin{array}{l}\text { Pelvis: Tape line between } \\
\text { ipsilateral ASIS \& PSIS } \\
\text { Lower limb: Tape marker just dis- } \\
\text { tal to ipsilateral greater trochan- } \\
\text { ter \& just proximal to ipsilateral } \\
\text { lateral malleolus }\end{array}$ & $\begin{array}{l}\text { Pulley driven } 5 \text { min- } \\
\text { ute passive straight } \\
\text { leg raise. }\end{array}$ & $\begin{array}{l}85.5^{\circ} \mathrm{HF} \text { accompanied by } 22.9^{\circ} \\
\mathrm{PPT}(26.8 \% \text { of motion }) . \\
\text { Correlation of } \mathrm{HF} \& \mathrm{PPT}=0.93 .\end{array}$ \\
\hline $\begin{array}{l}\text { Bohannon } \\
\text { et al. }(1985)^{3)}\end{array}$ & $\begin{array}{l}\text { Healthy young } \\
\text { males \& females } \\
(n=17)\end{array}$ & Supine & $\begin{array}{l}\text { Pelvis: Tape line between left } \\
\text { ASIS \& PSIS } \\
\text { Lower limb: Tape marker just dis- } \\
\text { tal to ipsilateral greater trochan- } \\
\text { ter \& just proximal to ipsilateral } \\
\text { lateral malleolus }\end{array}$ & $\begin{array}{l}\text { Manual passive } \\
\text { straight leg raise. }\end{array}$ & $\begin{array}{l}87.3^{\circ} \mathrm{HF} \text { accompanied by } 32.1^{\circ} \\
\text { PPT ( } 36.8 \% \text { of motion). } \\
\text { Mean correlation of total HF \& } \\
\text { PPT }=0.99 .\end{array}$ \\
\hline $\begin{array}{l}\text { Bohannon } \\
\text { et al. }(1985)^{4)}\end{array}$ & $\begin{array}{l}\text { Healthy young } \\
\text { males \& females } \\
(n=17)\end{array}$ & Supine & $\begin{array}{l}\text { Pelvis: Tape line between } \\
\text { ipsilateral ASIS \& PSIS } \\
\text { Lower limb: Tape marker just dis- } \\
\text { tal to ipsilateral greater trochan- } \\
\text { ter \& just proximal to ipsilateral } \\
\text { lateral femoral condyle }\end{array}$ & $\begin{array}{l}\text { Active and passive } \\
\text { unilateral \& bilateral } \\
\text { HF (knee free). }\end{array}$ & $\begin{array}{l}\text { Active unilateral: } 124.3^{\circ} \mathrm{HF} \\
\text { accompanied by } 34.2^{\circ} \mathrm{PPT}\left(27.5^{\circ}\right. \\
\text { of motion). } \\
\text { Active bilateral: } \\
138.4^{\circ} \mathrm{HF} \text { accompanied by } 43.7^{\circ} \\
\text { PPT ( } 31.6^{\circ} \% \text { of motion). } \\
\text { Passive unilateral: } 125.9^{\circ} \mathrm{HF} \text { ac- } \\
\text { companied by } 35.4^{\circ} \mathrm{PPT}(28.1 \%) \text {. } \\
\text { Passive bilateral: } 123.7^{\circ} \mathrm{HF} \text { ac- } \\
\text { companied by } 37.8^{\circ} \mathrm{PPT}\left(30.6^{\circ} \%\right. \\
\text { of motion). } \\
\text { Correlation of } \mathrm{HF} \& \mathrm{PPT} \text { ranged } \\
\text { from } 0.89 \text { to } 1.00 \text {. }\end{array}$ \\
\hline $\begin{array}{l}\text { Elia et al. } \\
(1996)^{7)}\end{array}$ & $\begin{array}{l}\text { Healthy young } \\
\text { male \& female } \\
\text { therapists }(n=13) \\
\text { Healthy young } \\
\text { male \& female } \\
\text { nontherapists } \\
(n=13)\end{array}$ & Supine & $\begin{array}{l}\text { Pelvis: Circular markers on ipsi- } \\
\text { lateral PSIS \& ASIS } \\
\text { Lower limb: Circular markers on } \\
\text { ipsilateral greater trochanter \& } \\
\text { lateral femoral epicondyle }\end{array}$ & $\begin{array}{l}\text { Active bilateral HF } \\
\text { (knee free) }\end{array}$ & $\begin{array}{l}\text { Therapists: } 90.0^{\circ} \mathrm{HF} \text { accompa- } \\
\text { nied by } 21.0^{\circ} \mathrm{PPT}(23.3 \%) \text {. } \\
\text { Nontherapists: } 90^{\circ} \mathrm{HF} \text { accompa- } \\
\text { nied by } 19.2^{\circ} \mathrm{PPT}(21.3 \%)\end{array}$ \\
\hline $\begin{array}{l}\text { Murray et al. } \\
(2002)^{9)}\end{array}$ & $\begin{array}{l}\text { Healthy young } \\
\text { males \& females } \\
(n=14)\end{array}$ & $\begin{array}{l}\text { Standing } \\
\text { upright }\end{array}$ & $\begin{array}{l}\text { Pelvis: Spherical reflective mark- } \\
\text { ers on ipsilateral PSIS \& ASIS } \\
\text { Lower limb: Spherical } \\
\text { reflective marker just distal to } \\
\text { ipsilateral greater trochanter \& } \\
\text { just proximal to ipsilateral lateral } \\
\text { femoral condyle }\end{array}$ & $\begin{array}{l}\text { Active unilateral hip } \\
\text { flexion (right) with } \\
\text { \& without resistance } \\
\text { (knee free) }\end{array}$ & $\begin{array}{l}\text { Not weighted: } 102.3^{\circ} \mathrm{HF} \text { accom- } \\
\text { panied by } 19.1^{\circ} \mathrm{PPT} \text { ( } 18.7 \% \text { of } \\
\text { motion). } \\
\text { Weighted: } 98.3^{\circ} \mathrm{HF} \text { accompanied } \\
\text { by } 21.1^{\circ} \mathrm{PPT}(21.5 \% \text { of motion). } \\
\text { Mean correlation of HF \& } \\
\text { PPT }=0.96 \text { to } 0.97 \text {. }\end{array}$ \\
\hline $\begin{array}{l}\text { Dewberry et } \\
\text { al. }(2003)^{6)}\end{array}$ & $\begin{array}{l}\text { Healthy males \& } \\
\text { females }(n=14)\end{array}$ & $\begin{array}{l}\text { Hanging by } \\
\text { hands from } \\
\text { bar with } \\
\text { back rested } \\
\text { against board } \\
\text { inclined } 10^{\circ} \\
\text { from vertical }\end{array}$ & $\begin{array}{l}\text { Pelvis: Spherical reflective mark- } \\
\text { ers on ipsilateral PSIS \& ASIS } \\
\text { Lower limb: Spherical } \\
\text { reflective marker just distal to } \\
\text { ipsilateral greater trochanter \& } \\
\text { just proximal to ipsilateral lateral } \\
\text { femoral condyle }\end{array}$ & $\begin{array}{l}\text { Active bilateral hip } \\
\text { flexion with knees } \\
\text { flexed or extended } \\
\text { (knee free) }\end{array}$ & $\begin{array}{l}\text { Short intrinsic hamstring length } \\
\text { ( }<78^{\circ} \text { SLR) \& knee extended: } 90^{\circ} \\
\text { HF accompanied by } 31.9^{\circ} \mathrm{PPT} \\
(35.5 \% \text { of motion). } \\
\text { Short intrinsic hamstring length } \\
\text { ( }<78^{\circ} \text { SLR) \& knee flexed: } 90^{\circ} \mathrm{HF} \\
\text { accompanied by } 17.1^{\circ} \mathrm{PPT}(19.0 \% \\
\text { of motion). } \\
\text { Long hamstring length }\left(>78^{\circ}\right. \\
\text { SLR) \& knee extended: } 90^{\circ} \mathrm{HF} \\
\text { accompanied by } 19.0^{\circ} \mathrm{PPT}(21.1 \% \\
\text { of motion). } \\
\text { Long hamstring length ( }>78^{\circ} \\
\text { SLR) \& knee flexed: } 90^{\circ} \text { of } \mathrm{HF} \\
\text { accompanied by } 11.8^{\circ} \mathrm{PPT}(13.1 \% \\
\text { of motion). }\end{array}$ \\
\hline
\end{tabular}


Continuation of Table 1.

\begin{tabular}{|c|c|c|c|c|c|}
\hline Article & Participants & $\begin{array}{c}\text { Postural } \\
\text { orientation }\end{array}$ & $\begin{array}{c}\text { Component } \\
\text { segment marking }\end{array}$ & $\begin{array}{l}\text { Hip flexion } \\
\text { task specifics }\end{array}$ & $\begin{array}{c}\text { Pelvifemal } \\
\text { rhythm findings }\end{array}$ \\
\hline $\begin{array}{l}\text { Congdon et } \\
\text { al. }(2005)^{5)}\end{array}$ & $\begin{array}{l}\text { Healthy young } \\
\text { males \& females } \\
(\mathrm{n}=31)\end{array}$ & Supine & $\begin{array}{l}\text { Pelvis: Spherical reflective } \\
\text { markers on ipsilateral PSIS \& } \\
\text { ASIS } \\
\text { Lower limb: Spherical reflec- } \\
\text { tive marker just distal to ipsi- } \\
\text { lateral greater trochanter \& just } \\
\text { proximal to proximal portion of } \\
\text { ipsilateral knee brace }\end{array}$ & $\begin{array}{l}\text { Active bilateral hip } \\
\text { flexion with knees } \\
\text { braced at } 0^{\circ}, 45^{\circ} \text {, } \\
\text { and } 90^{\circ}\end{array}$ & $\begin{array}{l}\text { Short hamstring length }\left(<75^{\circ}\right. \\
\text { SLR), knee } 0^{\circ}: 70^{\circ} \mathrm{HF} \text { accom- } \\
\text { panied by } 25.9^{\circ} \mathrm{PPT} \text { ( } 37.0^{\circ} \% \text { of } \\
\text { motion). } \\
\text { Short hamstring length, knee } \\
45^{\circ}: 70^{\circ} \mathrm{HF} \text { accompanied by } \\
21.4^{\circ} \mathrm{PPT} \text { ( } 30.6 \% \text { of motion). } \\
\text { Short hamstring length, knee } \\
90^{\circ}: 70^{\circ} \mathrm{HF} \text { accompanied by } \\
17.6^{\circ} \mathrm{PPT}(25.1 \% \text { of motion). } \\
\text { Long intrinsic hamstring } \\
\left.\text { length ( }>75^{\circ} \mathrm{SLR}\right), \text { knee } 0^{\circ}: \\
70^{\circ} \mathrm{HF} \text { accompanied by } 21.7^{\circ} \\
\mathrm{PPT}(31.0 \% \text { of motion). } \\
\text { Long hamstring length, knee } \\
45^{\circ}: 70^{\circ} \mathrm{HF} \text { accompanied by } \\
19.7^{\circ} \mathrm{PPT}(28.1 \% \text { of motion). } \\
\text { Long hamstring length, knee } \\
90^{\circ}: 70^{\circ} \mathrm{HF} \text { accompanied by } \\
17.6^{\circ} \mathrm{PPT}(25.1 \% \text { of motion). }\end{array}$ \\
\hline $\begin{array}{l}\text { Gatti et al. } \\
(2006)^{8)}\end{array}$ & $\begin{array}{l}\text { Healthy young } \\
\text { males \& females } \\
(\mathrm{n}=20)\end{array}$ & Supine & $\begin{array}{l}\text { Pelvis: Spherical reflective } \\
\text { marker on ipsilateral ASIS } \\
\text { Lower limb: Spherical reflec- } \\
\text { tive marker on ipsilateral } \\
\text { greater trochanter \& lateral } \\
\text { femoral condyle }\end{array}$ & $\begin{array}{l}\text { Active unilateral hip } \\
\text { flexion with knee } \\
\text { braced at } 60^{\circ} \& \\
\text { loads of } 0 \mathrm{~kg}, 2 \mathrm{~kg} \& \\
8 \mathrm{~kg} \text { applied }\end{array}$ & $\begin{array}{l}0 \mathrm{~kg} \text { load: } 40^{\circ} \mathrm{HF} \text { accom- } \\
\text { panied by median } 9.5^{\circ} \mathrm{PPT} \\
(23.8 \% \text { of motion). } \\
2 \mathrm{~kg} \text { load: } 40^{\circ} \mathrm{HF} \text { accompa- } \\
\text { nied by median } 10^{\circ} \mathrm{PPT}(25 \% \\
\text { of motion). } \\
8 \mathrm{~kg} \text { load: } 40^{\circ} \mathrm{HF} \text { accom- } \\
\text { panied by median } 15^{\circ} \mathrm{PPT} \\
(37.5 \% \text { of motion). }\end{array}$ \\
\hline $\begin{array}{l}\text { Van Houcke } \\
\text { et al. } \\
(2013)^{10)}\end{array}$ & $\begin{array}{l}\text { Healthy young } \\
\text { males }(\mathrm{n}=12) \\
\text { Young males with } \\
\text { FAI }(\mathrm{n}=17)\end{array}$ & Supine & $\begin{array}{l}\text { Pelvis: Magnetic sensor fixed to } \\
\text { skin over contra-lateral ASIS } \\
\text { Lower limb: Magnetic sen- } \\
\text { sor fixed to orthosis worn on } \\
\text { ipsilateral distal thigh }\end{array}$ & $\begin{array}{l}\text { Active and passive } \\
\text { unilateral hip flexion } \\
\text { (knee free) }\end{array}$ & $\begin{array}{l}\text { Healthy active: } 113.4^{\circ} \mathrm{HF} \text { ac- } \\
\text { companied by } 9.1^{\circ} \mathrm{PPT}(8.0 \% \\
\text { of motion). } \\
\text { FAI active: } 105.9^{\circ} \mathrm{HF} \text { accom- } \\
\text { panied by } 12.5^{\circ} \mathrm{PPT}(11.8 \% \text { of } \\
\text { motion). } \\
\text { Healthy passive: } 118.9^{\circ} \mathrm{HF} \text { ac- } \\
\text { companied by } 10.0^{\circ} \mathrm{PPT}(8.4 \% \\
\text { of motion). } \\
\text { FAI passive: } 110.1^{\circ} \mathrm{HF} \text { accom- } \\
\text { panied by } 10.5^{\circ} \mathrm{PPT}(9.5 \% \text { of } \\
\text { motion). }\end{array}$ \\
\hline
\end{tabular}

ASIS: anterior superior iliac spine; PSIS: posterior iliac spine; HF: hip flexion; PPT: posterior pelvic tilt; FAI: femoroacetabular impingement

Angular measurements are means unless otherwise designated.

\section{RESULTS}

Database and hand searches yielded 203 non-duplicative articles. Of these, 9 ( 2 from hand-searches) were retained based on inclusion and exclusion criteria.

All retained articles described the measurement of pelvifemoral rhythm in healthy young men and women. However, one article addressed pelvifemoral rhythm in participants with femoroacetabular impingement as well ${ }^{10)}$. The studies included 11 to 31 participants. Pelvifemoral rhythm was examined while participants were in 1 of 3 postural orientations: supine $(\mathrm{n}=7)^{2-5,7,8)}$, standing $(\mathrm{n}=1)^{9)}$, hanging from a bar $(\mathrm{n}=1)^{6}$. The capture of pelvic position during HF involved a tape line ${ }^{2-4)}$ 
Table 2. Summary of quality ratings of articles included in systematic review

\begin{tabular}{lccccccccc}
\hline \multicolumn{1}{c}{ Study } & Item 1 & Item 2 & Item 3 & Item 4 & Item 5 & Item 6 & Item 7 & Item 8 & Total \\
\hline Bohannon $(1982)^{2)}$ & 1 & 1 & 0 & 3 & 2 & 2 & 1 & 1 & 11 \\
Bohannon et al. (1985) & 1 & 2 & 0 & 3 & 2 & 2 & 1 & 0 & 11 \\
Bohannon et al. $(1985)^{4)}$ & 1 & 2 & 0 & 3 & 2 & 2 & 1 & 1 & 12 \\
Congdon et al. $(20)^{5)}$ & 2 & 2 & 0 & 3 & 2 & 2 & 1 & 0 & 12 \\
Dewberry et al. $(2003)^{6)}$ & 2 & 2 & 0 & 3 & 2 & 0 & 1 & 0 & 10 \\
Elia et al. $(1996)^{7)}$ & 2 & 2 & 0 & 3 & 2 & 1 & 0 & 1 & 11 \\
Gatti et al. $(2006)^{8)}$ & 2 & 2 & 0 & 3 & 2 & 1 & 0 & 0 & 10 \\
Murray et al. (2002) & 2 & 3 & 0 & 3 & 2 & 2 & 1 & 1 & 14 \\
Van Houcke et al. $(2013)^{10)}$ & 2 & 3 & 1 & 3 & 2 & 2 & 1 & 0 & 14 \\
\hline
\end{tabular}

Items and scoring: 1) Participant inclusion/exclusion criteria explicit (2), 2) Sample adequately described: type, demographics (age, gender), anthropometrics (height, weight) (3), 3) Enrollment consecutive with timeframe (2), 4) Task described: Posture, hip flexion-active vs passive, unilateral vs bilateral (3), 5) Measurement adequately described: markers, motion capture (2), 6) Summary statistics (mean/median, SD/SE/range) provided for LE and pelvis (2), 7) Relationship between pelvic and lower limb motion described ( $\mathrm{r}$ or graphically) (1), 8) Reliability of measures addressed (1)

or tape markers ${ }^{7}$ in early studies. Later, spherical reflective markers ${ }^{5,6,8,9)}$ or a magnetic sensor ${ }^{10)}$ were used. The capture of lower limb movement involved tape markers ${ }^{2-4,7)}$, spherical reflective markers $5,6,8,9$ ), or a magnetic sensor ${ }^{10)}$ on the lateral distal thigh or lateral leg proximal to the malleolus (when HF was performed in the context of straight-leg-raising). The manner in which HF was performed varied considerably. Specifically, it was performed passively $\left.{ }^{2-4}, 10\right)$ and actively ${ }^{4-10}$, unilaterally $^{2-4,8-10)}$ and bilaterally ${ }^{4-7)}$, and with the knee extended ${ }^{2,3,5,6)}$ and flexed ${ }^{4-9)}$.

The mean HF excursion over which pelvifemoral rhythm was examined ranged from $40.0^{\circ}$ to $138.4^{\circ}$. The mean contribution of pelvic tilt to total HF ranged from a mean $13.1 \%$ to $37.5 \%{ }^{6}$. Pelvic tilt tended to make a greater contribution to HF when the knee was extended rather than flexed and when the hamstrings were shorter rather than longer ${ }^{5,6)}$. Pelvic tilt began almost as soon as HF and was highly correlated with HF regardless of postural orientation, method of motion capture, or specifics of the HF task ( $\mathrm{r}=0.89$ to 1.00$)^{2-4,9)}$.

The quality score of articles consolidated in this systematic review ranged from 10 to 14 (out of a possible 16 points). The most common shortcoming was a failure to clarify enrollment specifics.

\section{DISCUSSION}

The purpose of this review was to synthesize what is known about the coordinated movement of the thigh and pelvis (pelvifemoral rhythm) during HF. All the literature reviewed showed that pelvifemoral rhythm underlies the performance of $\mathrm{HF}^{2-10)}$ just as scapulohumeral rhythm underlies the performance of shoulder elevation ${ }^{13)}$. The literature also indicated that the contribution of pelvic tilting to $\mathrm{HF}^{3-6,9,10)}$, like the contribution of scapular rotation to shoulder elevation ${ }^{13)}$, begins very early and continues throughout the range of motion. Consequently, attempts to stabilize the pelvis or limit the measurement of HF until posterior tilting of the pelvis begins ${ }^{14}$, makes no sense.

The contribution of pelvic tilt to HF varies widely but appears to be influenced by hamstring length as it tends to be greater when individuals have shorter hamstrings (a lower straight leg raising angle) or when the hamstrings are put on stretch (the knee is extended). This follows as a pull of the hamstrings on their insertion (ischial tuberosity) has the potential to foster a posterior pelvic tilt. As pelvic tilting occurs during both passive and active HF, it appears that the motion is not dependent on activation of the muscles that actively tilt the pelvis posteriorly (ie, rectus abdominus).

Our systematic review has several limitations. First, all studies but one used surface markers to capture movement of the ipsilateral pelvis and thigh. No study incorporated markers or sensors on both sides of the pelvis. Second, the studies had relatively small samples of young adults, with only one study involving individuals with a known pathology. Larger samples, as well as samples involving older adults and patients, should be examined to determine whether pelvifemoral rhythm differs between groups. Such groups might include patients with impaired hip or lumbar spine range of motion (eg, ankylosing spondylitis) or weak hip flexor or abdominal muscles (eg, stroke), or athletes for whom hip flexion is particularly important (eg, gymnasts). It would be interesting to know if pelvifemoral rhythm has implications or is modifiable in such groups. Third, the heterogeneity of studies included in this review precluded our conducting a meta-analysis. We are left, therefore, only able to indicate that pelvifemoral rhythm is a reality that should be considered when HF is performed under various circumstances.

\section{Conflicts of interest}

The authors have no conflicts of interest to declare. 


\section{REFERENCES}

1) Azevedo DC, Paiva EB, Lopes AM, et al.: Pelvic rotation in femoroacetabular impingement is decreased compared to other symptomatic hip conditions. J Orthop Sports Phys Ther, 2016, 46: 957-964. [Medline] [CrossRef]

2) Bohannon RW: Cinematographic analysis of the passive straight-leg-raising test for hamstring muscle length. Phys Ther, 1982, 62: 1269-1274. [Medline] [CrossRef]

3) Bohannon R, Gajdosik R, LeVeau BF: Contribution of pelvic and lower limb motion to increases in the angle of passive straight leg raising. Phys Ther, 1985, 65: 474-476. [Medline] [CrossRef]

4) Bohannon RW, Gajdosik RL, LeVeau BF: Relationship of pelvic and thigh motions during unilateral and bilateral hip flexion. Phys Ther, 1985, 65: 1501-1504. [Medline] [CrossRef]

5) Congdon R, Bohannon R, Tiberio D: Intrinsic and imposed hamstring length influence posterior pelvic rotation during hip flexion. Clin Biomech (Bristol, Avon), 2005, 20: 947-951. [Medline] [CrossRef]

6) Dewberry MJ, Bohannon RW, Tiberio D, et al.: Pelvic and femoral contributions to bilateral hip flexion by subjects suspended from a bar. Clin Biomech (Bristol, Avon), 2003, 18: 494-499. [Medline] [CrossRef]

7) Elia DS, Bohannon RW, Cameron D, et al.: Dynamic pelvic stabilization during hip flexion: a comparison study. J Orthop Sports Phys Ther, 1996, 24: 30-36. [Medline] [CrossRef]

8) Gatti R, Corti M, Cervi P, et al.: Biomechanics of lower limb raising from the supine position. Eura Medicophys, 2006, 42: 185-193. [Medline]

9) Murray R, Bohannon R, Tiberio D, et al.: Pelvifemoral rhythm during unilateral hip flexion in standing. Clin Biomech (Bristol, Avon), 2002, 17: 147-151. [Medline] [CrossRef]

10) Van Houcke J, Pattyn C, Vanden Bossche L, et al.: The pelvifemoral rhythm in cam-type femoroacetabular impingement. Clin Biomech (Bristol, Avon), 2014, 29: 63-67. [Medline] [CrossRef]

11) Kuo YL, Tully EA, Galea MP: Lumbofemoral rhythm during active hip flexion in standing in healthy older adults. Man Ther, 2010, 15: 88-92. [Medline] [CrossRef]

12) Tully EA, Wagh P, Galea MP: Lumbofemoral rhythm during hip flexion in young adults and children. Spine, 2002, 27: E432-E440. [Medline] [CrossRef]

13) Crosbie J, Kilbreath SL, Hollmann L, et al.: Scapulohumeral rhythm and associated spinal motion. Clin Biomech (Bristol, Avon), 2008, 23: 184-192. [Medline] [CrossRef]

14) Norkin CC, White DJ: Measurement of joint motion. A guide to goniometry, 5th ed. Philadelphia: FA Davis, 2016. 